\title{
Microemulsion Based Bioadhesive Gel of Itraconazole Using Tamarind Gum: In-vitro and Ex-vivo Evaluation
}

\author{
Kailas K Mali, Shashikant C Dhawale, Remeth J Dias
}

\begin{abstract}
The current study was aimed to formulate and evaluate bioadhesive gel containing microemulsion (ME) of itraconazole (ITZ) and an attempt was made to investigate suitability of tamarind gum (TG) as a gelling agent. The solubility of ITZ in oils, surfactants and co-surfactant was evaluated for the selection of appropriate component. The ratio of surfactant and co-surfactant was optimized by constructing pseudoternary phase diagram. Ternary phase diagram was constructed using isopropyl myristate (IPM) and oleic acid (OA) as oil phase, tween 80 as surfactant and isopropyl alcohol (IPA) as cosurfactant in order to obtain ME region. The optimized ME of ITZ was characterized by its qualitative and quantitative tests and incorporated into polymeric gels of carbopol (CBP), xanthan gum (XG) and TG. The ME based ITZ gels were evaluated for $\mathrm{pH}$, drug content, viscosity, ex-vivo bioadhesion, spreadability and in vitro drug release. Furthermore, antifungal activity of
\end{abstract}

the gels was performed by agar cup diffusion technique using cultures of Candida albicans. ITZ showed maximum solubility in mixture of IPM and OA (1:1). Stable ME was obtained when IPM and OA was taken in the ratio of $1: 1$ as oil phase, Tween 80 as surfactant and isopropyl alcohol (IPA) as cosurfactant at the weight ratio of 10:45:45. The optimized ME based gels showed $\mathrm{pH}$ in the range of 6.11 to 6.48 , spreadability in the range of 4.1 to $7.1 \mathrm{gm} . \mathrm{cm} / \mathrm{sec}$ and ex vivo bioadhesion in the range of 65 to $84 \mathrm{gm}$. The viscosity study indicated pseudoplastic behaviour of all ME based gel formulations. Amongst the studied ME gels, TG containing gels exhibited fast and complete drug release at the end of $24 \mathrm{~h}$. Formulation F7 containing TG showed wide zone of inhibition and found to be stable for three months. These results indicate that the TG containing ME gel may be a used as vehicle for topical delivery of drugs.

Keywords: bioadhesion, itraconazole, microemulsion gel, tamarind gum, xanthan gum.
Kailas K Mali, Remeth J Dias

YSPM's, Yashoda Technical Campus, Faculty of Pharmacy, Wadhe, Satara, 415011 (MS) India

Shashikant C Dhawale

School of Pharmacy, SRTM University, Nanded 431606 (MS) India

Corresponding Author:

Kailas Krishnat Mali

e-mail:malikailas@gmail.com
Submitted / Gönderilme: 20.01.2017

Accepted / Kabul: $\quad 05.04 .2017$

Revised / Düzeltme: 03.04.2017

\section{INTRODUCTION}

Approximately two third of population throughout the world is affected by a common fungal infection(1). The fungal infections caused by genus Candida, Aspergillus, and Cryptococcus are showing increasing trends of infections more specifically in transplant patients, AIDS patients and cancer patients. The major cause of morbidity and mortality in patients has been invasive fungal infections(2).

Itraconazole (ITZ) is a triazole antifungal agent with a wide spectrum of activity. It is well tolerated in patients as compared to other triazoles like fluconazole, ravuconazole, and posaconazole. ITZ is used in the treatment of fungal infections. ITZ is drug of choice in case of immunecompromised and non-immuno compromised patients along with patients who cannot tolerate amphotericin B therapy (3). However, ITZ is a highly hydrophobic weak base and shows inter-individual and intra-individual variability in oral bioavailability. ITZ being BCS class II drug, its absorption 
from gastrointestinal tract is incomplete and dose dependent after oral ingestion. Moreover, ITZ has shown adverse effects like constipation, abdominal pain, headache and rarely cardiac failure. The contraindication of ITZ in patients with renal and/or hepatic impairment is also an disadvantage $(4,5)$.

Topical agents like creams and ointments are very sticky which may cause uneasiness to patients on application and have less spreading coefficient which necessitates rubbing. Therefore, the gels have gained importance in both pharmaceutical and cosmetics field due to their several advantages over other semisolid preparations(6). Gels are greaseless preparations which can easily spread and are compatible with several water soluble or miscible excipients(7). However, hydrophobic drugs cannot be delivered through conventional gel formulation(8). Therefore, emulsion based approach can be utilised for successfully delivering hydrophobic drugs through gels.

Microemulsions (MEs) have been growing in popularity due to unique characteristics and garnering more attention in recent years. Such interest has come from industrial laboratories, as well as academic researchers and in pharmaceutical fields, this has lead to their application in various administration routes. The stable MEs can be easily prepared which can improve solubilising efficiency of both hydrophilic and lipophilic drugs which in turn can increase permeability of drugs (9). However, the low viscosity of ME pose problem of applicability to skin and decreases the patient compliance(10). MEs or ME gels significantly enhance the absorption of drugs compared with solution, gel or cream formulations(9). Combination of MEs with bioadhesive gel may be a promising approach to treat topical infection.

The use of natural polymers in delivery system is cost effective due to its easy availability. Moreover, they are biodegradable, biocompatible and are easily accepted by regulatory authorities(11). The use of polymers such as carbopol (CBP), poloxamer, hydroxylpropyl methylcellulose and natural polymer such as xanthan gum (XG) as gelling agents in the formulation of ME gels were reported in the literatures(2,12-14). Tamarind gum (TG) is a natural polymer well known for its applicability in food industry. It consists of neutral branched polysaccharide chain having cellulose like backbone(15). Recently, TG has attracted the formulation scientists for its application in drug delivery systems(16-20). Also, it is used in development of bioadhesive drug delivery systems due to its hydrophilic and bioadhesive properties(21-24). However, no study has been reported till date, where TG has been used as gelling agent in ME based gel formulation.
Thus, it was proposed to formulate and evaluate $\mathrm{ME}$ containing ITZ based bioadhesive gels of CBP, XG and TG for improved delivery of hydrophobic drug. Further investigation was made to evaluate ex vivo bioadhesion, viscosity, drug release, kinetics of drug release and antifungal activity of prepared gels. The prepared ME based gel may overcome the gastric side effects of ITZ, retain on skin for extended period of time and capacity to treat fungal infections with improved therapeutic outcome.

\section{MATERIALS AND METHODS}

\subsection{Materials}

ITZ was procured from USV Ltd., Mumbai as a gift sample. Oleic acid (OA), isopropyl myristate (IPM), Tween 80, isopropyl alcohol (IPA), light liquid paraffin, olive oil, Tween 20, Tween 80, polyethylene glycol 400 (PEG 400), xanthan gum and Carbopol 934P were purchased from Loba Chemie, Mumbai. Tamarind gum was prepared in our laboratory. All other chemicals were of analytical grade and purchased from Loba Chemie, Mumbai.

\subsection{Solubility study of ITZ}

Oils and excipients were selected on the criteria of highest solubility of ITZ in it. Light liquid paraffin, IPM, OA and olive oil were selected on the basis of literature available which proved an effective excipient for formulation of ME.

The screening of various oils was done by determining solubility of ITZ in various oils. The oil showing highest solubility of ITZ was used as oil phase of ME. The surfactants (Tween 80 and Tween 20) and cosurfactants (PEG 400 and IPA) were also screened to determine solubility of ITZ in them.

The determination of solubility was carried out by adding an excess amount of ITZ to stoppered vials (30ml capacity) containing $10 \mathrm{ml}$ of oil, surfactant and cosurfactant. The preliminary mixing was done using magnetic stirrer (Remi, India) and further sonicated for $30 \mathrm{~min}$. After sonication, shaking of these vials was carried out for 72 hours at $37 \pm 0.5^{\circ} \mathrm{C}$ using shaker (BioTechnics, India). The centrifugation of these equilibrated samples was carried out at $5000 \mathrm{rpm}$ for $20 \mathrm{~min}$. Was filtered using membrane filter and used for analysis after with methanolic $\mathrm{HCl}$. The analyte was analysed by using UVVis spectrophotometer (Shimadzu, Japan) at 262nm. Each experiment was repeated thrice(3). 


\subsection{Construction of pseudoternary phase diagram}

The four component system comprising of oil phase, aqueous phase, a non-ionic surfactant and cosurfactant was used to construct pseudoternary phase diagram. The optimisation of surfactant and cosurfactant ratio $(\mathrm{Km})$ was done by estimating the area covered by ME in pseudoternary phase diagram on varying concentrations of surfactant and cosurfactant.

The homogenous liquid mixture of oil phase, surfactant, cosurfactant and water was titrated at ambient temperature for constructing the pseudoternary phase diagram. Nine mixtures of varying concentration of surfactant and cosurfactant (total quantity $2 \mathrm{gm}$ ) in the ratio of 1:9 to 9:1 were prepared. The fixed quantity of water $(2 \mathrm{gm})$ was added to these mixtures uniformly and mixed. Then, dropwise oil was added till the clear and transparent formulations are turned into a slightly cloudy state. The vortex mixer was used for stirring during the titration which ensured equilibrium.

The pseudoternary phase diagram was constructed by taking oil, surfactant and cosurfactant as vertices while water ratio was kept unvaried. ME window was marked by considering the region where clear and transparent mixtures were obtained which were confirmed upon visual inspection (25).

\subsection{Construction of Ternary Phase Diagram}

The best weight ratio of surfactant and cosurfactant $(\mathrm{Km})$ was finalised from the results of pseudoternary phase diagram. A homogenous blend of oil and surfactant-cosurfactant (Smix) was prepared by keeping $\mathrm{Km}$ fixed and varying the contents of oil and Smix from 1:9 to 9:1. The quantity of blend was fixed to $1.0 \mathrm{gm}$ while purified water was added drop by drop to each mixture. The magnetic stirrer was used to stir the samples during titration. The addition of water dropwise was carried out till the clear and transparent solution turns into a slightly cloudly state(4). The ternary phase diagram was constructed by marking the region where you get the clear and transparent ME.

\subsection{Preparation of ITZ ME}

Smix ratio with maximum ME region was selected for preparation of ME. Five different batches from this region were prepared by dissolving ITZ in the mixture of oil and Smix. The prepared mixtures were mixed at ambient temperature using magnetic stirrer (Remi, India). Then double distilled water was added drop by drop to this oily mixture till clear and transparent ME was obtained. The mixture was stirred gently for 15-20min using magnetic stirrer for allowing it to stabilize and attain equilibrium. All MEs containing ITZ were then stored at ambient temperature(26).

\subsection{Qualitative and Quantitative tests for ME}

One millilitre of prepared $\mathrm{ME}(\mathrm{s})$ were diluted to $100 \mathrm{ml}$ for performing dilution test. The diluted samples were visually inspected for clarity, turbidity and phase separation. The identification of type of ME was done using a water soluble dye, methyl orange which was sprinkled on the MEs and observed under microscope (10X, Motic PA 210). Centrifugation test was used to evaluate physical stability of ME. MEs were centrifuged (Remi, India) at $5000 \mathrm{rpm}$ for $30 \mathrm{~min}$ and system was evaluated for creaming or phase separation by visual observation. The $\mathrm{pH}$ of ME was determined by using digital $\mathrm{pH}$ meter (Systronics, India).

Electrical conductivity of ME was checked at ambient temperature with digital conductivity meter (Systronics, Mumbai). The percentage transmittance of MEs was measured against distilled water using UV-VIS spectrophotometer (Shimadzu, Japan) at $650 \mathrm{~nm}$ (27).

Drug content of ME was measured in order to ensure dose uniformity. ME equivalent to $5 \mathrm{mg}$ of ITZ was taken in 50 $\mathrm{ml}$ volumetric flask containing $0.1 \mathrm{~N}$ methanolic $\mathrm{HCl}$ and stirred for $30 \mathrm{~min}$. Then volume was made up to $50 \mathrm{ml}$ with $0.1 \mathrm{~N}$ methanolic $\mathrm{HCl}$. From the above solution, $2 \mathrm{ml}$ was further diluted with $0.1 \mathrm{~N}$ methanolic $\mathrm{HCl}$. The filtration of resultant solution was done using $0.45 \mu \mathrm{m}$ membrane filter. The absorbance of the solution was measured at $262 \mathrm{~nm}$ wavelength using UV-Vis spectrophotometer (Shimadzu, Japan)(28).

Dispersion stability studies were performed to ensure stability of ME. Formulations were centrifuged at $3000 \mathrm{rpm}$ for 30 min. The formulations without any phase separation were subjected to heating and cooling cycle (freeze thaw cycle). Six cycles within temperatures range of $4^{\circ} \mathrm{C}$ (in a refrigerator) to $45^{\circ} \mathrm{C}$ (in a hot air oven) were performed for $48 \mathrm{~h}$. The formulations showing stability at these temperatures were selected for further studies(29).

\subsection{Preparation of ME based gels of ITZ}

Blank gels of different polymers were prepared by using distilled water. In brief, the required quantity of polymer was dispersed in $100 \mathrm{ml}$ distilled water and mixed for $60 \mathrm{~min}$ on 
mechanical stirrer (Remi, India). The $\mathrm{pH}$ of carbopol gel was adjusted to 6-6.5 using triethanolamine where as sodium tetraborate was used for TG gels (30). For ME preparation, initially preservative was mixed well in mixture of oil blend and Smix. Then ITZ was dissolved in above mixture under magnetic stirring at ambient temperature. The double distilled water was added drop by drop to the oily mixture till clear and transparent MEs were obtained. The mixture was stirred gently for $15-20 \mathrm{~min}$ using magnetic stirrer for allowing it to stabilize and attain equilibrium. All MEs containing ITZ were then stored at ambient temperatures. Prepared gels and MEs were mixed in the ratio of 1:1(31). Details of formulation batches are given in following Table 1.

\subsection{Characterization of ITZ containing ME based gels}

\section{Attenuated total reflectance-Fourier transform infrared spectroscopy}

The infrared spectra of ITZ, ME based gels were obtained using attenuated total reflectance-Fourier transform infrared (ATR-FTIR) spectrophotometer (Shimadzu, IR Affinity, Japan). The samples to be analyzed were transferred to the ATR compartment. The spectra were obtained for the range of $600-4000 / \mathrm{cm}$ at an average of 25 scans and resolution of $4 / \mathrm{cm}$.

\section{Physical examination}

Prepared ME based gel formulations were investigated for physical characteristics like colour, homogeneity and phase separation(32).

\section{Drug Content}

Drug content of ME based gel was determined by UV spectrophotometer. Gram of ME gel was diluted to 100 $\mathrm{ml}$ with $0.1 \mathrm{~N}$ methanolic $\mathrm{HCl}$ and sonicated for $10 \mathrm{~min}$. Then solution was filtered and diluted suitably with $0.1 \mathrm{~N}$ methanolic $\mathrm{HCl}$. The absorbance of the resulting solution was measured spectrophotometrically (UV 1800, Shimadzu, Japan) at $262 \mathrm{~nm}(8)$.

\section{Spreadability study}

Spreadability of ME based gel was determined by placing 0.5 $\mathrm{g}$ of gel within a circle of $1 \mathrm{~cm}$ diameter pre- marked on a glass plate. Another glass plate was kept over it and 500gm weight was placed on this upper for $5 \mathrm{~min}$. The gel spreading was noted from the change in diameter of gel placed(33).

\section{Determination of $p H$}

The $\mathrm{pH}$ of ME based gel was determined by using digital $\mathrm{pH}$ meter (Systronics, Mumbai), at ambient room temperature. ME based gel was accurately weighed and dispersed in $50 \mathrm{ml}$ purified water to make $10 \%$ solution. The calibration of $\mathrm{pH}$ meter was done with buffered solution before each use (34).

\section{Ex vivo bioadhesive strength measurement}

The bioadhesive strength was measured by using a modified balance method. In this method, which two pans of physical balance were removed and plastic glass was tied on right side while a glass vial was hanged on left side. The assembly was

Table 1. Formulation of ME based gels

\begin{tabular}{lccccccccc}
\hline Formulation Code & F1 & F2 & F3 & F4 & F5 & F6 & F7 & F8 & F9 \\
\hline Gel & & & & & & & & & \\
Carbopol 934 P & 1 & 2 & 3 & - & - & - & - & - & - \\
Xanthan Gum & - & - & - & 1 & 2 & 3 & - & - & - \\
TG & - & - & - & - & - & - & 2 & 3 & 4 \\
Methyl paraben & 0.8 & 0.8 & 0.8 & 0.8 & 0.8 & 0.8 & 0.8 & 0.8 & 0.8 \\
Distilled water to & 100 & 100 & 100 & 100 & 100 & 100 & 100 & 100 & 100 \\
ME & & & & & & & & & \\
Drug & 2 & 2 & 2 & 2 & 2 & 2 & 2 & 2 & 2 \\
IPM+OA (1:1) & 10 & 10 & 10 & 10 & 10 & 10 & 10 & 10 & 10 \\
Smix & 45 & 45 & 45 & 45 & 45 & 45 & 45 & 45 & 45 \\
Water & 45 & 45 & 45 & 45 & 45 & 45 & 45 & 45 & 45 \\
Propyl Paraben & 0.4 & 0.4 & 0.4 & 0.4 & 0.4 & 0.4 & 0.4 & 0.4 & 0.4 \\
\hline
\end{tabular}

${ }^{\star}$ All quantities are given in \%; TG- Tamarind gum; IPM- Isopropyl myristate; OA- Oleic acid; Smix-Tween 80: isopropyl alcohol (6:4). 
balanced by adding extra weights on right side. Both the vials are placed in such a way that one glass vial will be in inverted position and another in upright position. A portion of chicken back skin was tied to both vials with rubber. One gram of gel was placed between two vials and water was added dropwise until the ME based gel was separated from chicken back skin. Volume of water required to detach vials was measured and converted to mass. This gives the bioadhesive strength of gel in $\operatorname{grams}(35)$.

\section{Viscosity Studies}

A cone and plate viscometer with spindle C75-2 (Brookfield, USA) was used to determine viscosity of different ME gels.

\section{In vitro drug release}

One gram from each ME based gel formulation containing drug equivalent to $5 \mathrm{mg}$ was placed on semi permeable cellulosic cellophane membrane previously soaked in distilled water for $12 \mathrm{~h}$. The loaded membrane with the sample of ME based gel was stretched over one end of open glass tube area $\left(1.7 \mathrm{~cm}^{2}\right)$. The membrane was tied tightly over the tube end by means of a rubber. The tube was suspended so that membrane was one centimeter just below the surface of Tris $\mathrm{HCl}$ buffer ( $\mathrm{pH}$ 7.4): methanol (70:30) containing $1 \%$ SLS in $100 \mathrm{ml}$ beaker and shaken thermostatically at $100 \mathrm{rpm}$ at specific time interval. At predetermined time intervals aliquots were withdrawn and replaced with fresh buffer solution. The amount of ITZ released was analysed by using UV-VIS spectrophotometer (Shimadzu, Japan) at $262 \mathrm{~nm}(36)$.

\section{Antifungal activity study}

The prepared gels containing ME of ITZ formulations were tested against Candida albicans using agar cup method. Petri plates containing sabouraud dextrose agar were inoculated with tested fungal strain and cups of $10 \mathrm{~mm}$ diameter were bored aseptically. The formulation was poured in these cups. The petridishes were incubated in the incubator at $37^{\circ} \mathrm{C}$ for $24 \mathrm{~h}$. After $24 \mathrm{~h}$, the zone of inhibition was measured and compared to the control(37). The control sample was prepared with ITZ in oil blend (IPM and OA in the ratio of 1:1). Experiments were carried out in triplicate.

\section{Stability study}

The prepared optimised ME based gel was stored away from light in polyethylene bottles at $40^{\circ} \mathrm{C}$ and $4{ }^{\circ} \mathrm{C}$ for three months. Sample was withdrawn at the end of three months and evaluated for physical appearance, $\mathrm{pH}$, drug content, spreadability and viscosity.

\section{RESULTS AND DISCUSSION}

\subsection{Solubility of ITZ}

ITZ solubility in various solvents was varied from 2.1 to $68.03 \mathrm{mg} / \mathrm{ml}$ and is given in Table 2. ITZ is considered as poorly soluble drug. Therefore, it's very critical to ensure maximum solubility of ITZ in oily phase of ME so that stability and percutaneous delivery of the formulation is not affected. In order to increase solubility of ITZ in oil phase, combination of IPM and OA was tried in various ratios. ITZ showed marked increase of solubility in IPM and OA in the ratio of 1:1. Among tested surfactants and cosurfactants ITZ showed maximum solubility in Tween 80 and IPA as shown in Table 3. By considering solubility of ITZ, mixture of IPM and $\mathrm{OA}$ in the ratio of 1:1 was used as oil phase, tween 80 as a surfactant and IPA as a co-surfactant. Added advantage of IPM and OA was also considered as they promote skin permeation of drugs while selecting oil phase $(3,38)$.

Table 2. Solubility of ITZ in various solvents

\begin{tabular}{lll}
\hline Sr. No. & Oils & $\begin{array}{l}\text { Solubility } \\
(\mathbf{m g} / \mathbf{m l})\end{array}$ \\
\hline 1 & IPM & $60.21 \pm 1.78$ \\
2 & OA & $68.03 \pm 1.42$ \\
3 & IPM+OA $(1: 1)$ & $110.45 \pm 1.69$ \\
4 & Olive oil & $26.78 \pm 1.47$ \\
5 & Light liquid paraffin & $15.49 \pm 1.53$ \\
& Surfactants & $3.14 \pm 0.59$ \\
6 & Tween 20 & $7.36 \pm 0.46$ \\
7 & Tween 40 & $14.69 \pm 0.52$ \\
8 & Tween 80 & \\
& Co-surfactants & $3.7 \pm 0.19$ \\
9 & IPA & $2.1 \pm 0.23$ \\
10 & Ethanol & \\
\hline
\end{tabular}

IPM: isopropyl myristate; OA: oleic acid; IPA: isopropyl alcohol Data expressed in mean $\pm \mathrm{SD}, \mathrm{n}=3$

\section{2 Construction of Pseudoternary Phase Diagram}

The pseudoternary phase diagrams of oil blend (IPM and OA in the ratio of 1:1)/IPA/ Tween 80 / water system were constructed as shown in Figure 1. The region giving clear and transparent formulation was considered as the ME window and was marked in pseudoternary phase diagram. The best weight ratio of surfactant and cosurfactant $(\mathrm{Km})$ was found 
to be $6: 4$ and therefore the optimum surfactant mixture (Smix) of Tween 80 and IPA in the ratio of 6:4 was mixed with highest oil blend (IPM+OA) for further studies.

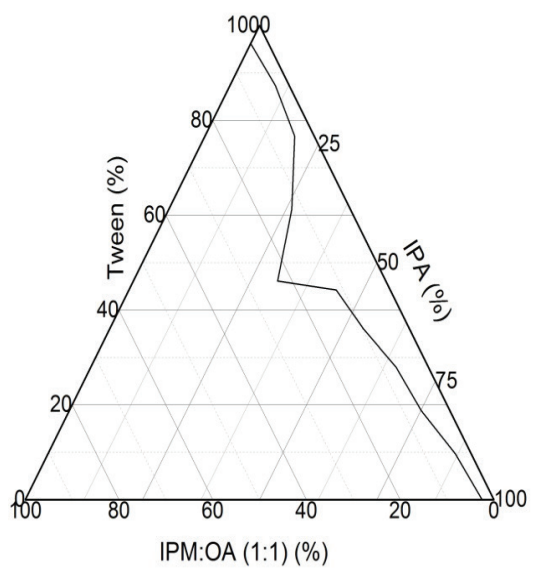

Figure 1. Pseudoternary phase diagram of mixture of isopropyl myristate and oleic acid- IPM:OA; Tween 80, isopropyl alcohol (IPA) and water.

\subsection{Ternary Phase Diagram}

The region of $\mathrm{ME}$ and concentration ranges of components used for formulation of ME were determined by phase studies. The effect of different surfactant / cosurfactant weight ratios on the extent of stable $\mathrm{ME}$ region was also studied. Phase diagram of the system containing oil blend / Smix/water system was constructed and is given in Figure 2. Black region in the Figure 2 indicates non-ME region and white region is the $\mathrm{ME}$ region. It is evident from the phase diagram that tween 80 and IPA could give considerable micro emulsification region (>40\%)(39). The different trial batches were prepared in order to confirm formation of o/w ME.

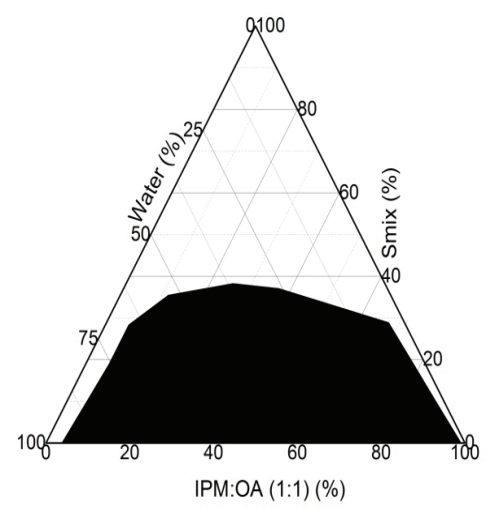

Figure 2. Phase diagram of mixture of isopropyl myristate and oleic acid- IPM:OA, mixed surfactant (Smix) and water.

\subsection{Preparation of ITZ MEs}

From the ternary phase diagram, Smix ratio with maximum $\mathrm{ME}$ region was selected. Oil-in-water $\mathrm{ME}$ was formed when the composition of oil blend:Smix:water at the weight ratio of 10:45:45 [M1], 10:50:40 [M2], 10:55:35 [M3], 10:60:30 [M4], 15:45:40 [M5] was used.

\subsection{Qualitative and quantitative tests of MEs}

Results of qualitative and quantitative tests of all prepared MEs are given in Table 3. In dilution test, all the batches of MEs showed no phase separation/turbidity except formulation F5. The type of ME formed was confirmed by dye test. In the ME, continuous phase is coloured and disperse phase is colourless. This is due to water soluble dye, methyl orange. All evaluated MEs were of o/w type. All $\mathrm{ME}$ formulations were found to be stable in centrifugation test except M3 and M5. Formulations M1, M2 and M4 do not showed creaming or phase separation. The $\mathrm{pH}$ values of microemulsions were varied in the range of 5.78 to 5.95 which was acceptable $\mathrm{pH}$ of skin (40). So, prepared ME formulations do not produce any irritation to the skin. All the formulations showed conductivity within the range of 80.7 to $96.45 \mu \mathrm{S}$. High conductivity values confirm the existence of o/w microemulsion. Generally, w/o formulations exhibit lower conductivity(41). Transmittance for all formulations was found to be in the range of 1.1 to $94.3 \%$. Formulation F5 showed less transmittance due to turbidity while formulation F4 showed high transmittance due to clarity.

All prepared microemulsions showed high drug content of about 95.5-98.3\%. This ensured uniformity of dose. The formulations which showed no phase separation (M1, M2, and M4) were taken for dispersion test. The formulation M1 was found to be stable at all the temperatures and was selected for further preparation of ME based gels.

\section{6 Evaluation of ITZ containing ME based gels}

\section{ATR-FTIR spectroscopy}

The IR spectrum of pure itraconazole shows characteristic peaks at $1585 \mathrm{~cm}^{-1}$ (C-N stretching), $1698 \mathrm{~cm}^{-1}$ (C=O stretching), 1128 $\mathrm{cm}^{-1}, 1183 \mathrm{~cm}^{-1}, 1139 \mathrm{~cm}^{-1}$ (aromatic C-H and C-N stretching), $3130 \mathrm{~cm}^{-1}, 3068 \mathrm{~cm}^{-1}$ (aromatic C-H stretching), $2964 \mathrm{~cm}^{-1}$, $2823 \mathrm{~cm}^{-1}$ (aliphatic C-H stretching). There were no additional peaks observed in formulations. Also specific peaks of drug were not observed in formulations (Figure 3). This may be due to the presence of the drug in minute concentration which 
Table 3. Results of qualitative and quantitative tests of microemulsions

\begin{tabular}{lccccc}
\hline Formulation code & M1 & M2 & M3 & M4 & M5 \\
\hline Dilution test & no phase separation & no phase separation & no phase separation & no phase separation & phase separation \\
Centrifugation/creaming & No & No & No & No & Yes \\
$\mathrm{pH}$ & 5.94 & 5.91 & 5.85 & 5.81 & 5.78 \\
Conductivity $(\mu \mathrm{S})$ & 96.45 & 93.21 & 86.94 & 85.67 & 90.74 \\
Transmittance $\%$ & 82.2 & 87.6 & 95.6 & 96.3 & 1.1 \\
Drug content & 98.3 & 95.5 & unstable & unstable & Unstable \\
Dispersion stability & Stable & unstable & & & \\
\hline
\end{tabular}

resulted in the subsiding of the peaks along with the peaks of the formulations. This indicates the absence of any potential physical or chemical interaction between drug and polymer and other formulation additives. So, it can be concluded that all the excipients were compatible with drug.

\section{Preparation of ME based gel of ITZ}

Optimised microemulsion of ITZ was incorporated in to the gel base prepared from the CBP, XG and TG. The minimum $2 \%$ of TG was required to form the smooth, viscous and consistent gel. Total nine formulations of ME based gels were formulated.

\section{Physical Examination}

All prepared ME based gel formulations were white/slightly buff, white viscous creamy preparation with a smooth homogeneous texture without phase separation. Gels prepared with TG and XG were found to be soft creamy while CBP gels were viscous creamy in nature.

\section{Drug content}

The calibration curve of ITZ in $0.1 \mathrm{~N}$ methanolic $\mathrm{HCl}$ was plotted. The regression equation was used for calculating drug content of the formulation. The drug content of all ME based gel formulations were found to be in the range of 96104\% (Table 4).

\section{Determination of $\mathrm{pH}$}

The $\mathrm{pH}$ values of all MEs was determined and they were within the range of 6.1 to 6.6 (Table 4 ). As the $\mathrm{pH}$ values lies in the normal $\mathrm{pH}$ range of the skin, it may not produce any skin irritation(40).

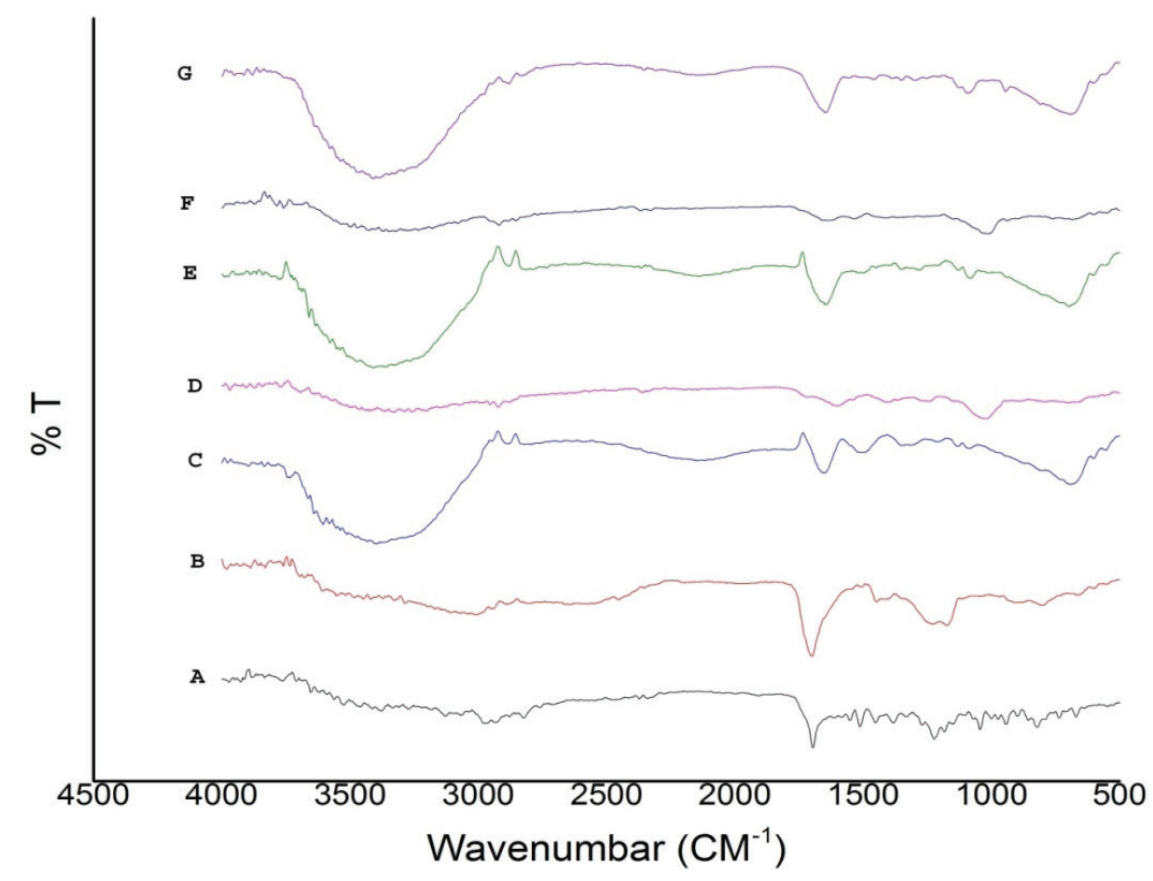

Figure 3. ATR-FTIR spectra of ITZ (A), carbopol (B), F2 (C), xanthan gum (D), F5 (E), tamarind gum (F), F8 (G) 


\section{Spreadability study}

The values of the spreadability of all formulations were found within the range of 4.1 to $9.3 \mathrm{gm} . \mathrm{cm} / \mathrm{sec}$ indicating that $\mathrm{ME}$ based gels were easily spreadable by small amount of shear. Formulation F7 exhibited maximum spreadability than all remaining formulations. Among the formulations containing equal amount of gelling agents (F2, F5, F7) TG containing gel exhibited good spreadability (Table 4 ). This could be due to low viscosity of TG gels. On increasing the concentration of each gelling agent in formulation, the spreadability of formulations was found to be decreased. This may be due to the properties of polymers to form hydrogen bonds, extent of swelling and flexibility of polymer chains which influences the spreadability of the formulation(33). Also, differences in viscosity of formulations affects spreadability as reported in literature(38).

\section{Ex vivo bioadhesive strength measurement}

The bioadhesive strength of various ME gel formulations is given in Table 4. The bioadhesion strength of ME gel formulations was found to be in the range of $56 \pm 1.4$ to $86 \pm 1.5$ (Table 4 ). The bioadhesive strength of TG formulations was found to be less than XG and CBP gels. This may be due to low viscosity of TG gels. Significant $(\mathrm{P}<0.05)$ increase in bioadhesive strength was observed with increase in concentration of each polymer. This may be attributed to the properties of polymer to form strong hydrogen bonding with the tissue, the availability of polymer chains to absorb water from tissue, swell and adhere to the tissue firmly(35).

Table 4. Evaluation of ME gels

\begin{tabular}{ccccc}
\hline $\begin{array}{c}\text { Formulation } \\
\text { code }\end{array}$ & $\begin{array}{c}\text { Drug } \\
\text { content }\end{array}$ & $\mathrm{pH}$ & $\begin{array}{c}\text { Spreadability } \\
\text { gm.cm/sec }\end{array}$ & $\begin{array}{c}\text { Bioadhesion } \\
\text { strength } \\
\text { (gm) }\end{array}$ \\
\hline F1 & $104.2 \pm 0.7$ & $6.48 \pm 0.12$ & $5.8 \pm 0.07$ & $68 \pm 0.7$ \\
F2 & $103.4 \pm 4.1$ & $6.43 \pm 0.06$ & $5.2 \pm 0.07$ & $76 \pm 1.4$ \\
F3 & $104.6 \pm 2.2$ & $6.58 \pm 0.02$ & $4.1 \pm 0.21$ & $84 \pm 0.7$ \\
F4 & $103.1 \pm 3.1$ & $6.11 \pm 0.02$ & $6.6 \pm 0.04$ & $69 \pm 1.4$ \\
F5 & $100.9 \pm 2.4$ & $6.23 \pm 0.02$ & $6.2 \pm 0.14$ & $78 \pm 2.8$ \\
F6 & $102.7 \pm 3.3$ & $6.19 \pm 0.01$ & $5.4 \pm 0.21$ & $86 \pm 1.5$ \\
F7 & $101.4 \pm 4.6$ & $6.14 \pm 0.02$ & $7.1 \pm 0.21$ & $65 \pm 2.8$ \\
F8 & $96.50 \pm 2.4$ & $6.36 \pm 0.01$ & $6.4 \pm 0.07$ & $73 \pm 1.4$ \\
F9 & $96.80 \pm 1.4$ & $6.23 \pm 0.05$ & $5.9 \pm 0.04$ & $81 \pm 0.7$ \\
\hline
\end{tabular}

Data expressed in mean \pm SD

\section{Viscosity study}

The viscosity results helped to understand the influence of various formulation parameters on consistency, spreadability and drug release. Generally consistency of formulations depends on the ratio of solid fraction to liquid fraction which produces gel structure. Formulation containing CBP (F1-F3) exhibited high viscosity than other formulations (Table 5). This is due to difference in the type of gelling agent which results in changing the structure consistency and low hygroscopicity of CBP 943 as compared to TG and XG(42). The type and the concentration of the gelling agent used played an important role in the topical preparation design since it affects the viscosity of the ME gels (31).

Table 5. Viscosities of ME based gels of ITZ

\begin{tabular}{ccc}
\hline Formulation code & $\begin{array}{c}\mathbf{h}^{*} \max \\
(\mathbf{c P})\end{array}$ & $\begin{array}{c}\mathbf{h}^{* *} \text { min } \\
(\mathbf{c P})\end{array}$ \\
\hline F1 & 210.1 & 2676.1 \\
F2 & 547.5 & 6199.5 \\
F3 & 862.2 & 9356.3 \\
F4 & 180.5 & 1410.1 \\
F5 & 232.1 & 2030.4 \\
F6 & 260.3 & 3322.2 \\
F7 & 120.8 & 932.3 \\
F8 & 178.7 & 1459.2 \\
F9 & 261.9 & 2156.3 \\
\hline
\end{tabular}

${ }^{*}$ Viscosity at high shear rate $(100 \mathrm{rpm})$;

${ }^{\star \star}$ Viscosity at low shear rate $(11.5 \mathrm{rpm})$.

All prepared formulations exhibited a shear thinning behaviour as the viscosity was found to be decreased by increasing the shear rate (Figure 4). When the shear is applied the disruption of point of contact takes place and structure of polymeric chain is broken down. Therefore less resistance to flow is seen and the release of entrapped inner phase leads to lower viscosity. Shear thinning behaviour is a desirable property for the topically applied preparations(13). Since, all prepared formulations showed pseudoplastic behaviour, it indicates good spreadability.

\section{In vitro drug release study}

All the batches of ITZ ME gels exhibited drug release within the range of 62.79 to $98.74 \%$ at the end of $24 \mathrm{~h}$ (Figure 5). CBP gels showed less drug release in comparison with 

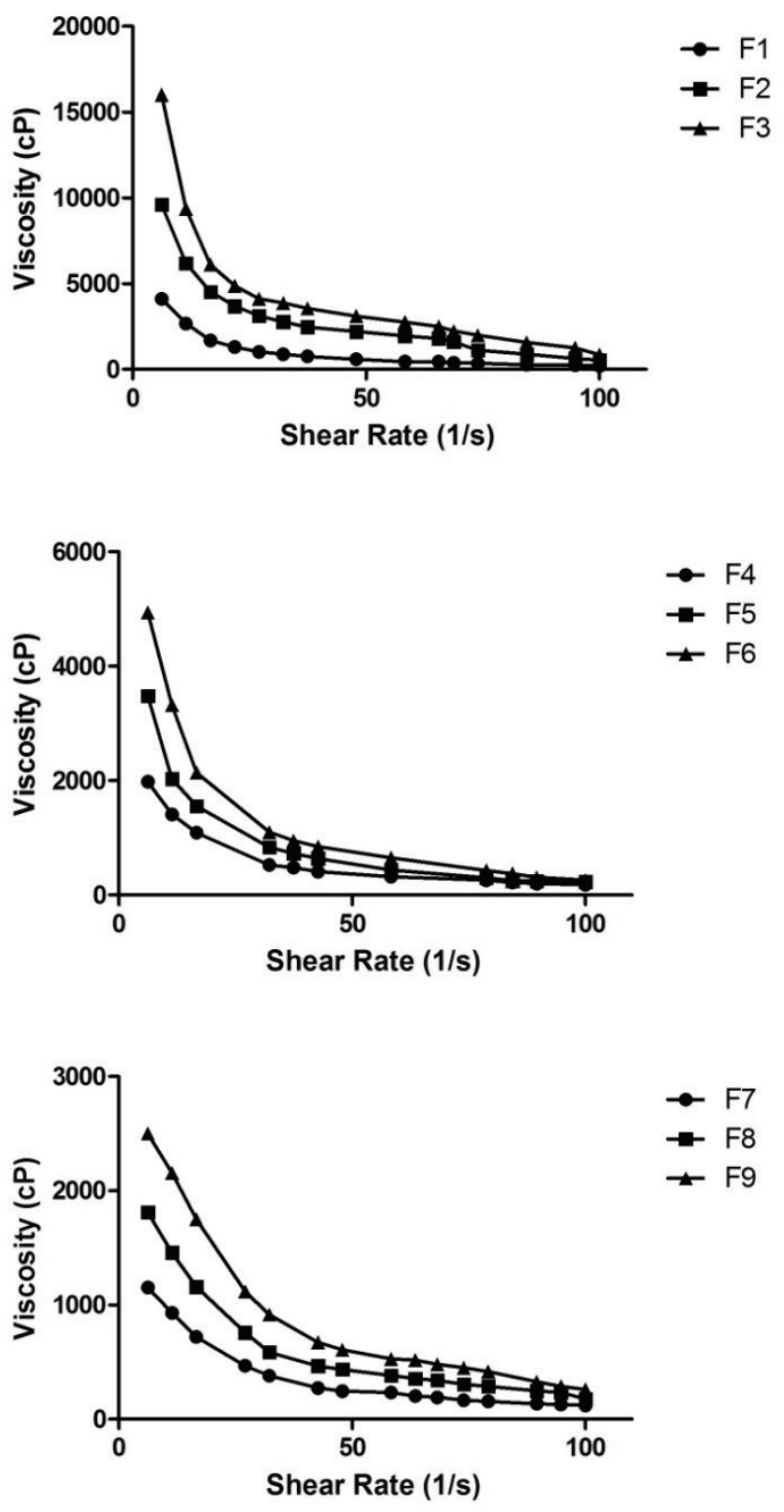

Figure 4. Effect of shear rate on viscosity of ME gels gels formulated with XG and TG. Carbopol is chemically polyacrylic acid polymer. After neutralisation of carboxyl groups CBP gets ionised and exerts electrostatic repulsion among charged polymer chains(43) thereby improves swelling and retards drug release. Formulations containing TG showed highest drug release amongst studied gelling agents. As concentration of TG was increased in formulations the drug release was found to be decreased. This may be due to formation of structured polymeric network developed by the sodium tetraborate(44) and leading to increased viscosity of formulations. Amongst the formulations containing equal amount of polymer, TG containing formulations exhibited fast drug release than CBP and XG. This may be due to the difference in the viscosity of the gels which was evident from viscosity study. TG forms weak gel in presence of sodium tetraborate which could be possible reason for the improvement in diffusion of drug through gel matrix of TG formulations than the CBP and XG in to the bulk of solution.

The release data was fitted to various kinetic models, including zero-order, Korsemeyer-Peppas and Higuchi diffusion model(45). The formulations F1, F2 and F8 followed Higuchi diffusion model while remaining all formulations followed Korsemeyer-Peppas diffusion model (Table 6). The value of release exponent was found to be in the range of 0.4 to 0.9 . When concentration of gelling agent was increased in formulation, drug release mechanism changed form fickian diffusion to anomalous diffusion. This indicates that the rate-controlling stage in the release process was diffusion of the dissolved drug through the gel network of polymers to the external medium. The formulation F4 containing XG exhibited low MDT while formulation F7 containing TG showed maximum DE.

Table 6. Release kinetics of ME based ITZ gels

\begin{tabular}{|c|c|c|c|c|c|c|c|}
\hline \multirow{2}{*}{$\begin{array}{l}\text { Formulation } \\
\text { Code }\end{array}$} & \multirow{2}{*}{$\begin{array}{c}\text { Drug release 24h } \\
(\%)\end{array}$} & \multicolumn{3}{|c|}{ Correlation coefficient } & \multirow[t]{2}{*}{$\mathrm{n}$} & \multirow{2}{*}{$\begin{array}{l}\text { MDT } \\
\text { (h) }\end{array}$} & \multirow{2}{*}{$\begin{array}{l}\mathrm{DE} \\
\text { (h) }\end{array}$} \\
\hline & & Zero order & Higuchi & $\begin{array}{c}\text { Korsemeyer } \\
\text { peppas }\end{array}$ & & & \\
\hline F1 & $77.33 \pm 2.52$ & 0.951 & 0.995 & 0.993 & 0.55 & 8.33 & 50.48 \\
\hline F2 & $69.97 \pm 2.42$ & 0.968 & 0.997 & 0.992 & 0.69 & 8.89 & 44.04 \\
\hline F3 & $62.79 \pm 2.06$ & 0.993 & 0.988 & 0.997 & 0.73 & 10.60 & 35.03 \\
\hline F4 & $81.23 \pm 1.99$ & 0.916 & 0.982 & 0.994 & 0.40 & 7.03 & 57.66 \\
\hline F5 & $75.70 \pm 1.61$ & 0.917 & 0.982 & 0.989 & 0.45 & 7.30 & 52.66 \\
\hline F6 & $70.86 \pm 1.38$ & 0.939 & 0.991 & 0.992 & 0.52 & 8.01 & 47.20 \\
\hline F7 & $98.74 \pm 3.54$ & 0.925 & 0.984 & 0.995 & 0.40 & 7.31 & 68.64 \\
\hline F8 & $85.42 \pm 3.21$ & 0.978 & 0.993 & 0.984 & 0.49 & 8.78 & 53.84 \\
\hline F9 & $72.79 \pm 4.62$ & 0.996 & 0.969 & 0.996 & 0.91 & 11.36 & 38.09 \\
\hline
\end{tabular}

n-release exponent; MDT-mean dissolution time; DE-dissolution efficiency 

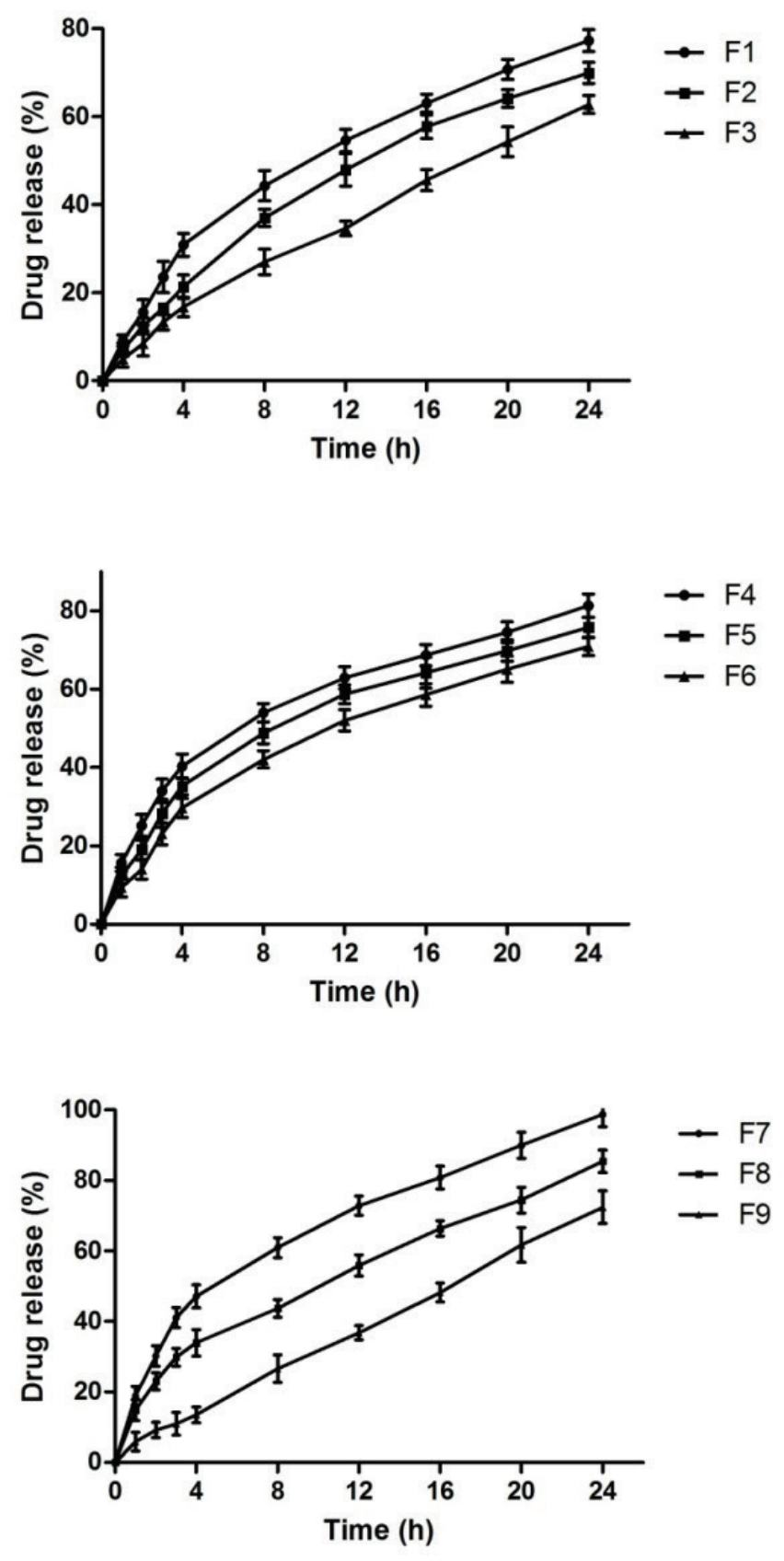

Figure 5. In vitro drug release of ITZ from ME based gels

\section{Antifungal activity study}

The plain ME gels were found to be microbiologically inert where as all prepared formulations showed inhibitory activity against fungal growth (Candida albicans) compared with the control. Formulation F7 shows superior inhibition zone diameter $27.66 \mathrm{~mm}$ than all studied formulations. The zone of inhibition depends on the viscosity of the formula studied. As viscosity was increased the zone of inhibition was found to be decreased.

Table 7. Antifungal activity of ME based gel of ITZ

\begin{tabular}{cc}
\hline $\begin{array}{c}\text { Formulation } \\
\text { Code }\end{array}$ & $\begin{array}{c}\text { Zone of inhibition } \\
(\mathbf{m m})\end{array}$ \\
\hline Control & $13.16 \pm 0.76$ \\
F1 & $18.83 \pm 1.6$ \\
F2 & $16.0 \pm 0.86$ \\
F3 & $12.16 \pm 0.57$ \\
F4 & $21.16 \pm 1.04$ \\
F5 & $18.5 \pm 1.32$ \\
F6 & $16.83 \pm 1.25$ \\
F7 & $27.66 \pm 0.76$ \\
F8 & $24.33 \pm 1.25$ \\
F9 & $21.16 \pm 0.76$ \\
\hline
\end{tabular}

Data expressed in mean $\pm S D, n=3$

Formulation F7 was optimised on the basis of $\mathrm{pH}$, spreadability, drug release and antifungal activity and further used for the stability study.

\section{Stability study}

The physical appearance, $\mathrm{pH}$, drug content, spreadability and viscosity of optimised formulation were investigated to evaluate the stability. The optimised formulation after three month stability was found to be smooth, viscous and consistent without phase separation. The results of stability study indicated that optimised formulation was stable for three months period (Table 6).

Table 8. Stability study of optimised ME gel of ITZ

\begin{tabular}{ccccccccc}
\hline $\begin{array}{c}\text { Storage } \\
\text { Temperature }\end{array}$ & \multicolumn{2}{c}{ pH } & \multicolumn{2}{c}{ Drug content } & \multicolumn{2}{c}{$\begin{array}{c}\text { Spreadability } \\
\text { (gm.cm/sec) }\end{array}$} & \multicolumn{2}{c}{$\begin{array}{c}\text { Viscosity } \\
(\mathbf{c P})\end{array}$} \\
& Before & After & Before & After & Before & After & Before & After \\
\hline $4^{\circ} \mathrm{C}$ & $6.14 \pm 0.02$ & $6.13 \pm 0.01$ & $101.4 \pm 4.6$ & $101.4 \pm 2.3$ & $7.1 \pm 0.21$ & $7.1 \pm 0.35$ & 1459.2 \\
$40^{\circ} \mathrm{C}$ & $6.14 \pm 0.02$ & $6.12 \pm 0.02$ & $101.4 \pm 4.6$ & $101.3 \pm 3.5$ & $7.1 \pm 0.21$ & $7.1 \pm 0.25$ & 1459.2 & 1461.5 \\
\hline
\end{tabular}

Data expressed in mean $\pm \mathrm{SD} ; \mathrm{n}=3$ 


\section{CONCLUSION}

The ITZ ME was successfully incorporated in to bioadhesive gels of CBP, XG and TG. The ITZ ME gel formulations prepared with TG showed acceptable spreadability, viscosity and ex vivo bioadhesion. TG formulations exhibited complete drug release and possess the greatest antifungal activity. The optimised formulation F7 was found to be stable for three months. The above results indicated potential application of natural polymers like TG in the development of ME based gels. Further in vivo studies will prove suitability of TG as a gelling agent in pharmaceutical application.

Tamarind reçinesi kullanılarak mikroemülsiyon yöntemiyle hazırlanan itrakonazol biyo-yapışkan jeli: in-vitro ve ex-vivo değerlendirme

Öz

$\mathrm{Bu}$ çalışmada, itrakonazol (ITZ) içeren biyo-yapışkan jel mikroemülsiyon (ME) yöntemiyle formüle edildi, değerlendirildi ve tamarind reçinesinin(TG) jelleştirici bir ajan olarak uygunluğu araştırıldı. ITZ'nin yağlar, yüzey aktif maddelerve yardımcı yüzey aktif maddeler içindeki çözünürlüğü uygun bileşenin seçimi için değerlendirildi. Yüzey aktif maddeler ve yardımcı yüzey aktif maddelerin oranı psödotersiyer faz diyagramı oluşturularak optimize edildi. Üçlü faz diyagramı yağ fazı olarak izopropil miristat (IPM) ve oleic asit (OA), yüzey aktif madde olarak tween 80 ve yardımcı yüzey aktif madde olarak izopropil alkol (IPA) kullanılarak hazırlandı ve ME bölgesi elde edildi. ITZ' nin ME’nu kalitatif ve kantitatif testler uygulanarak optimize edildi ve karbopol (CBP), ksantan reçinesi (XG) and TG'nin polimerik jellerine eklendi. ME yöntemiyle hazırlanan ITZ jelleri $\mathrm{pH}$, etken madde içeriği, viskozite, ex-vivo bioadezyon, yayılabilirlik ve in vitro ilaç salımı

\section{ACKNOWLEDGEMENTS}

Authors are thankful to USV Ltd., Mumbai for a providing itraconazole as gift sample. Authors are also thankful to Prof. Dasharath Sagare, Founder President, YSPM's Yashoda Technical Campus, Faculty of Pharmacy, Satara and Department of Microbiology, Yashwantrao Chavan College of Science, Satara for providing laboratory facilities.

\section{CONFLICT OF INTEREST}

All authors approve the final manuscript and declare that there are no conflicts of interests.

açısından değerlendirildi. Bu çalışmalara ek olarak jellerin ex vivo antifungal etkinlikleri Candida albicans kültürlerine karşı agar diffüzyon yöntemi kullanılarak saptandı. ITZ, IPM ve OA (1:1) karışımı içinde maksimum çözünürlük gösterdi. Stabil ME, yağ fazı olarak 1:1 oranında IPM : OA, yüzey aktif madde olarak Tween 80 ve yardımcı yüzey aktif madde olarak IPA ağırlık olarak 10:45:45 oranında kullanılarak elde edildi. ME yöntemiyle hazırlanan ve optize edilen jellerin $\mathrm{pH}$ aralığı 6.11 6.48 , yayılabilirliği $4.1-7.1 \mathrm{gm} . \mathrm{cm} / \mathrm{sn}$ ve ex vivo biyoadezyonu of 65 -84 gm olarak ölçüldü. Viskozite çalışmalarında ME yöntemine göre hazırlanna jel formülasyonlarının psödoplastik davranış gösterdiği tespit edildi. Çalışılan ME jelleri arasından TG içeren jellerin 24 saat sonunda hızlı ve kantitatif salım yaptığı görüldü. TG içeren formülasyon F7’nin geniş bir inhibisyon zonu meydana getirdiği ve üç ay müddetince stabil kaldığı görüldü. Elde edilen sonuçlar ışığında TG içeren ME jellerinin ilaçların topikal salınımı için umut vadeden sıvağlar olabileceği önerildi.

Anahtar kelimeler: Biyoadezyon, itrakonazol, mikroemülsiyon jel, tamarind reçinesi, ksantan reçinesi.

\section{REFERENCES}

1. Jain A, Jain S, Rawat S. Emerging fungal infections among children: A review on its clinical manifestations, diagnosis, and prevention. J Pharm Bioallied Sci 2010;2:314-20.

2. Chudasama A, Patel V, Nivsarkar M, Vasu Kamala. Investigation of microemulsion system for transdermal delivery of Itraconazole. J Adv Pharm Technol Res 2011;2:30-8.

3. Alam S, Iqbal Z, Ali A, Khar RK, Ahmad FJ, Akhter S, Talegaonkar S. Microemulsion as a potential transdermal carrier for poorly water soluble antifungal drug itraconazole. J Dispers Sci Technol. 2009;31:84-94.

4. Kumar N, Shishu. D-optimal experimental approach for designing topical microemulsion of itraconazole: Characterization and evaluation of antifungal efficacy against a standardized Tinea pedis infection model in Wistar rats. Eur J Pharm Sci 2015;67:97-112.

5. Grant SM, Clissold SP. Itraconazole. A review of its pharmacodynamic and pharmacokinetic properties, and therapeutic use in superficial and systemic mycoses. Drugs 1989;37:310-44.

6. Ambala R, Vemula SK. Formulation and characterization of ketoprofen emulgels. J Appl Pharm Sci 2015;5:112-7.

7. Mohamed MI. Optimization of chlorphenesin emulgel formulation. AAPS J 2004;6:e26.

8. Khunt DM, Mishra AD, Shah DR. Formulation design \& development of piroxicam emulgel. Int J PharmTech Res 2012;4:1332-44. 
9. Karasulu HY. Microemulsions as novel drug carriers: the formation, stability, applications and toxicity. Expert Opin Drug Deliv 2008;5:119-36.

10. Shah VV, Sharma M, Gandhi K, Suthar V, Parikh RK. Quality by Design (QbD) approach for optimization of microemulsion based topical gel. Marmara Pharm J 2016;20:415-24.

11. Mali KK, Dhawale SC. Design and optimization of modified tamarind gum-based floating-bioadhesive tablets of verapamil hydrochloride. Asian J Pharm 2016;10:2-8.

12. Boonme P, Kaewbanjong J, Sangduangyang S, Suksawat S, Teeranachaideekul V. Microemulsion-based hydrogels of itraconazole: Evaluation of characteristics and stability. Asian J Pharm Sci 2016;11:98-9.

13. Shahin M, Hady SA, Hammad M, Mortada N. Novel jojoba oil-based emulsion gel formulations for clotrimazole delivery. AAPS PharmSciTech 2011;12:239-47.

14. Fouad SA, Basalious EB, El-Nabarawi MA, Tayel SA. Microemulsion and poloxamer microemulsion-based gel for sustained transdermal delivery of diclofenac epolamine using in-skin drug depot: In vitro/in vivo evaluation. Int J Pharm 2013;453:569-78.

15. Goyal P, Kumar V, Sharma P. Carboxymethylation of Tamarind kernel powder. Carbohydr Polym 2007;69:251-5.

16. Shaw GS, Uvanesh K, Gautham SN, Singh V, Pramanik K, Banerjee I, Kumar N, Pal K. Development and characterization of gelatin-tamarind gum/carboxymethyl tamarind gum based phase-separated hydrogels:a comparative study. Des Monomers Polym 2015;18:434-50.

17. Kaur G, Jain S, Tiwary AK. Chitosan-carboxymethyl tamarind kernel powder interpolymer complexation: Investigations for colon drug delivery. Sci Pharm 2010;78:57-78.

18. Pal S, Sen G, Mishra S, Dey RK, Jha U. Carboxymethyl tamarind: Synthesis, characterization and its application as novel drug-delivery agent. J Appl Polym Sci 2008;110:392400.

19. Kaur H, Ahuja M, Kumar S, Dilbaghi N. Carboxymethyl tamarind kernel polysaccharide nanoparticles for ophthalmic drug delivery. Int J Biol Macromol 2012;50:833-9.

20. Madgulkar AR, Bhalekar MR, Padalkar RR, Shaikh MY. Optimization of carboxymethyl-xyloglucan-based tramadol matrix tablets using simplex centroid mixture design. J Pharm 2013;2013:1-11.

21. Datta R, Bandyopadhyay AK. A new nasal drug delivery system for diazepam using natural mucoadhesive polysaccharide obtained from tamarind seeds. Saudi Pharm J 2006;14:115-9.

22. Mali K, Dhawale S, Dias R, Havaldar V, Ghorpade V, Salunkhe N. Nasal mucoadhesive in situ gel of granisetron hydrochloride using natural polymers. J Appl Pharm Sci 2015;5:084-93.

23. Ghelardi E, Tavanti A, Davini P, Celandroni F, Salvetti S, Parisio E, Boldrini E, Senesi S, Campa M. A mucoadhesive polymer extracted from tamarind seed improves the intraocular penetration and efficacy of rufloxacin in topical treatment of experimental bacterial keratitis. Antimicrob Agents Chemother 2004;48:3396-401.

24. Avachat AM, Gujar KN, Wagh KV. Development and evaluation of tamarind seed xyloglucan-based mucoadhesive buccal films of rizatriptan benzoate. Carbohydr Polym 2013;91:537-42.
25. Hou P, Cao S, Ni J, Zhang T, Cai Z, Liu J, Wang Y, Wang $\mathrm{P}$, Lei $\mathrm{H}$, Liu Y. In-vitro and in-vivo comparison of T-OA microemulsions and solid dispersions based on EPDC. Drug Dev Ind Pharm 2015;41:263-71.

26. Barot BS, Parejiya PB, Patel HK, Mehta DM, Shelat PK. Microemulsion-based antifungal gel delivery to nail for the treatment of onychomycosis: Formulation, optimization, and efficacy studies. Drug Deliv Transl Res 2012;2:463-76.

27. Kumar M, Pathak K, Misra A. Formulation and characterization of nanoemulsion-based drug delivery system of risperidone. Drug Dev Ind Pharm 2009;35:387-95.

28. Hong JY, Kim JK, Song YK, Park JS, Kim CK. A new selfemulsifying formulation of itraconazole with improved dissolution and oral absorption. J Control Release 2006;110:332-8.

29. Kumar R, Sinha VR. Preparation and optimization of voriconazole microemulsion for ocular delivery. Colloids Surfaces B Biointerfaces 2014;117:82-8.

30. López-Cervantes M, Escobar-Chávez JJ, Casas-Alancaster N, Quintanar-Guerrero D, Ganem-Quintanar A. Development and characterization of a transdermal patch and an emulgel containing kanamycin intended to be used in the treatment of mycetoma caused by Actinomadura madurae. Drug Dev Ind Pharm 2009; 35:1511-21.

31. Khalil YI, Khasraghi AH, Mohammed EJ. Preparation and evaluation of physical and rheological properties of clotrimazole emulgel. Iraqui J Pharm Sci 2011;20:19-27.

32. Shen Y, Ling X, Jiang W, Du S, Lu Y, Tu J. Formulation and evaluation of Cyclosporin A emulgel for ocular delivery. Drug Deliv 2015;22:911-7.

33. Bachhav YG, Patravale VB. Formulation of meloxicam gel for topical application: In vitro and in vivo evaluation. Acta Pharm 2010;60:153-63.

34. Thakur NK, Bharti P, Mahant S, Rao R. Formulation and characterization of benzoyl peroxide gellified emulsions. Sci Pharm 2012;80:1045-60.

35. Naga Sravan Kumar Varma V, Maheshwari P V, Navya M, Reddy SC, Shivakumar HG, Gowda DV. Calcipotriol delivery into the skin as emulgel for effective permeation. Saudi Pharm J 2014;22:591-9.

36. Ismail A, Saleh KI, Ibrahim MA, Khalaf S. Effect of porous silica as a drug carrier on the release rate of naproxen from emulgel. Bull Pharm Sci 2006;29:224-35.

37. Wagh VD, Deshmukh OJ. Itraconazole niosomes drug delivery system and its antimycotic activity against Candida albicans. ISRN Pharm 2012;2012:Article ID 653435.

38. Üstündağ Okur N, Çağlar EŞ, Arpa MD, Karasulu HY. Preparation and evaluation of novel microemulsion-based hydrogels for dermal delivery of benzocaine. Pharm Dev Technol 2016;7450:1-11.

39. Bachhav YG, Patravale VB. Microemulsion based vaginal gel of fluconazole: Formulation, in vitro and in vivo evaluation. Int J Pharm 2009;365:175-9.

40. Yuan Y, Li SM, Mo FK, Zhong DF. Investigation of microemulsion system for transdermal delivery of meloxicam. Int J Pharm 2006;321:117-23.

41. Priya Moulik S, Kumar Rakshit A. Physicochemisty and applications of micro- emulsions. J Surf Sci Technol 2006;22:159-86. 
42. Sabri LA, Sulaiman HT, Khalil YI. An Investigation release and rheological properties of miconazole nitrate from emulgel and introduction. Iraqi J Pharm Sci 2009;18:26-31.

43. Li C, Liu C, Liu J, Fang L. Correlation between rheological properties, in vitro release, and percutaneous permeation of tetrahydropalmatine. AAPS PharmSciTech 2011;12:1002-10.
44. Coviello T, Matricardi P, Alhaique F, Farra R, Tesei G, Fiorentino S, Asaro F, Milcovich G, Grassi M. Guar gum / borax hydrogel: Rheological, low field NMR and release characterizations. eXPRESS Polym Lett 2013;7:733-46.

45. Costa P, Sousa Lo JM. Modeling and comparison of dissolution profiles. Eur J Pharm Sci 2001;13:123-33. 